\title{
Persistent serum immune complexes in syphilis
}

\author{
SIEGFRIED ENGEL AND WOLFGANG DIEZEL \\ From the Department of Dermatology and Venereology (Charité), Humboldt University, Berlin, East \\ Germany
}

SUMMARY Serum immune complexes were estimated by a polyethylene glycol precipitation method in 51 patients with early syphilis. The immune complexes were increased in $41 \%$ of patients before treatment and decreased to normal limits in only $56 \%$ during treatment. The results of the specific antitreponemal tests using dissolved immune complexes show that antibodies from the immune complexes are specific antibodies.

\section{Introduction}

The presence of circulating immune complexes (ICs) in early syphilis was first suggested by the evidence of ICs in syphilitic nephropathy. ${ }^{2}$ Using a radioimmunoassay, Sølling and his co-workers ${ }^{34}$ also demonstrated circulating ICs in early syphilis and in a case of syphilitic nephropathy. Gamble and Reardan ${ }^{5}$ found antitreponemal antibodies in the deposits of ICs by antibody elution tests performed on kidney biopsy material, and Tourville and co-workers ${ }^{6}$ demonstrated the presence of treponemal antigen using an indirect fluorescent antibody technique.

In this study, we looked for circulating ICs before and after treatment using a precipitation method and assessed the specificity of circulating ICs.

\section{Patients and methods}

Serum samples from 51 local patients with primary (6) and secondary (45) syphilis were investigated before treatment. Of the 43 men (aged 20-71 years), 35 were homosexuals and five were married; of the eight women (aged 18-44 years), four were married.

Serum samples from 38 patients were investigated before and once a week during treatment, the last time being after treatment.

\section{DIAGNOSIS}

The diagnosis was established by either darkground microscopy or serological tests-the fluorescent treponemal antibody absorption (FTA-ABS) test, the Treponema pallidum immobilisation (TPI) test, the

Address for reprints: Dr S Engel, Bereich Medizin (Charité), Humboldt-Universität zu Berlin, Hautklinik und Poliklinik, Schumannstrasse 20/21, 104 Berlin, GDR

Received for publication 10 September 1979
$T$ pallidum haemagglutination (TPHA) test, and the Venereal Disease Research Laboratory (VDRL) test.

\section{TREATMENT}

Patients were treated with 500000 units benzylpenicillin twice daily for 15 days and then with either benzathine benzylpenicillin/procaine benzylpenicillin retard 1200000 units three times weekly for 15 days or benzylpenicillin 1 megaunit twice daily for a further 15 days (in patients with abnormal cerebrospinal fluid samples).

\section{PRECIPITATION TECHNIQUE}

Serum ICs were estimated by the polyethylene glycol (PEG) precipitation method according to the technique of Diezel and co-workers. ${ }^{7}$ The principles of the method are precipitation of the ICs in barbital- $\mathrm{HCl}$ buffer $(\mathrm{pH} 8.4)$ containing 3.5\% PEG, sedimentation of the complexes by centrifugation at $12000 \times$ $g$, dissolution of the precipitates in Biurets reagent, and measurement of the optical density at $550 \mathrm{~nm}$ (protein determination).

The mean values determined in 100 healthy controls was $3.87 \mathrm{mg} / \mathrm{ml}$ serum (confidence interval $\mathrm{P}<0 \cdot 01$ ).

The ICs used to test the specificity of the antibodies in specific routine antitreponemal tests (the FTA-ABS, the TPI, and the TPHA tests) were washed three times with barbital-HCi buffer containing 3.5\% PEG and dissolved in $0.15 \mathrm{~mol} / \mathrm{l}$ $\mathrm{NaCl}$. The IC solution contained $5 \mathrm{mg}$ protein $/ \mathrm{ml}$ and was used instead of the patients' sera.

\section{Results}

ICs were increased in 21 of the 51 serum specimens obtained before treatment; 20 were from patients 
with secondary syphilis and one was from a patient with primary syphilis (table I). The ICs decreased to normal limits during treatment in only about $50 \%$ of patients (table II). This phenomenon did not depend on the kind of treatment or the daily dosage of penicillin.

Two specimens from patients with secondary syphilis containing increased amounts of ICs were tested by specific antitreponemal tests; the results were compared with those of two specimens from healthy controls (table III).

TABLE I Increased immune complexes in patients with primary and secondary syphilis before treatment

\begin{tabular}{lclc}
\hline & & \multicolumn{2}{l}{$\begin{array}{l}\text { Increased ICs before } \\
\text { treatment }\end{array}$} \\
\cline { 3 - 4 } Diagnosis & $\begin{array}{l}\text { No of } \\
\text { patients }\end{array}$ & No & $\%$ \\
\hline Primary syphilis & 6 & 1 & 16 \\
Secondary syphilis & 45 & 20 & 44 \\
Total & 51 & 21 & 41 \\
\hline
\end{tabular}

TABLE II Increased immune complexes in 38 patients with primary and secondary syphilis before and after treatment

\begin{tabular}{lll}
\hline & Increased ICs & \\
\cline { 2 - 3 } Diagnosis & Before treatment & After treatment \\
\hline Primary syphilis & 1 & 0 \\
Secondary syphilis & 15 & 7 \\
Total & 16 & $7(44 \%)$ \\
\hline
\end{tabular}

TABLE III Dissolved immune complexes from patients with secondary syphilis tested by specific antitreponemal tests

\begin{tabular}{llll}
\hline & \multicolumn{3}{c}{ IC detected by antitreponemal tests } \\
\cline { 2 - 4 } Specimens & FTA-ABS & $\begin{array}{l}\text { TPI (\% } \\
\text { immobilisation) }\end{array}$ & $\begin{array}{c}\text { TPHA } \\
\text { (titre) }\end{array}$ \\
\hline $\begin{array}{llll}\text { Secondary syphilis } \\
1\end{array}$ & + & $+/-(36)$ & $+(1 / 160)$ \\
2 & + & $+/-(28)$ & $+(1 / 160)$ \\
Control & & & \\
1 & - & $-(4)$ & - \\
2 & - & $-(0)$ & - \\
\hline
\end{tabular}

+ Positive; + / - weakly positive; - negative

\section{Discussion}

Using a sensitive precipitation method our investigations have shown that in nearly $50 \%$ of patients with secondary syphilis, and in some cases of primary syphilis, pathologically increased amounts of ICs can be found.

Contrary to the findings of Sølling and coworkers ${ }^{3}$ the ICs did not decrease to normal limits immediately after treatment. The present incomplete results of the continuing study also indicate that they do not decrease to normal limits a few months after treatment.

The results of the specific serological tests using dissolved ICs show that the antibodies from the ICs are specific antitreponemal antibodies.

Thus it can be concluded that (a) the antigen is a specific antigen from $T$ pallidum; and (b) the individual pool of ICs is enlarged by specific antigen antibody complexes. If this conclusion is correct $T$ pallidum must still be present in patients after treatment.

There is no doubt that specific antibodies are a constituent of the ICs. The ICs were washed until the supernatant was free of protein, especially of IgG detected by immunodiffusion. Provided that the specific antibodies are detected long after treatment, we consider that the continued serum reactivity after treatment is a consequence of the persisting presence of viable $T$ pallidum. This corresponds to the results of several investigators who have found evidence of $T$ pallidum in patients after treatment. ${ }^{89}$

\section{References}

1. Bhorade MS, Carag HB, Lee J, Potter EV, Dunea G. Nephropathy of secondary syphilis: a clinical and pathological spectrum. JAMA 1971;216:1159-66.

2. Braunstein GD, Lewis EJ, Galvanek EG, Hamilton A, Bell WR. The nephrotic syndrome associated with secondary syphilis: an immune deposit disease. Am J Med 1970; 48:643-8.

3. Sølling J, Sølling K, Jacobsen KU, From E. Circulating immune complexes in syphilis. Acta Derm Venereol (Stockh) 1978;58:263-7.

4. Sølling J, Sølling $\mathrm{K}$, Jacobsen $\mathrm{KU}$, Olsen S, From $\mathrm{E}$. Circulating immune complexes in syphilitic nephropathy. A case report. Br J Vener Dis 1978; 54:53-6.

5. Gamble CN, Reardan JB. Immunopathogenesis of syphilitic glomerulonephritis. Elution of antitreponemal antibody from glomerular immune complex deposits. $N$ Engl $J$ Med 1975; 292: 449-54.

6. Tourville DR, Lawrence HB, Kim DU, Zajd D, Lee J, Reichmann LB, Baskin St. Treponemal antigen in immunopathogenesis of syphilitic glomerulonephritis. Am J Pathol 1976; 82:479-92.

7. Diezel W, Meffert H, Günther W, Sönnichsen N. Quantitative estimation of serum immune complexes with a simple method. Dtsch Gesund Wes 1978; 33: 1822-3.

8. Tramont EC. Persistence of Treponema pallidum following penicillin G therapy. $J A M A$ 1976;236:2206-7.

9. Catterall, RD. Immunität im verlauf der syphilis. Hautarzt 1978; 29: 119-26. 